\title{
Karakteristik Batu Penyusun Candi Borobudur
}

\author{
Leliek Agung Haldoko, Rony Muhammad, dan Al. Widyo Purwoko \\ Balai Konservasi Borobudur \\ leliek_agung@yahoo.co.id
}

\begin{abstract}
Abstrak : Candi Borobudur merupakan salah satu warisan budaya Indonesia yang juga telah diakui sebagai salah satu warisan budaya dunia. Candi Borobudur tersusun oleh andesit yang jika diteliti secara lebih spesifik memiliki karakteristik yang berbeda-beda, sehingga memiliki tingkat kerusakan dan pelapukan yang berbeda. Penentuan karakteristik batu Candi Borobudur didasarkan pada parameter sifat fisik, komposisi kimia, dan mineralogi batuan.

Batu candi yang berwarna gelap memiliki densitas lebih besar dibandingkan batu candi yang berwarna cerah karena kandungan ferro magnesium-nya lebih tinggi. Selain itu batu candi yang berwarna gelap mampu menyerap panas lebih besar dibandingkan dengan batu candi yang berwarna cerah.

Batu candi yang ditumbuhi lumut memiliki densitas lebih kecil dan porositas lebih besar jika dibandingkan batu candi yang tidak ditumbuhi lumut. Kandungan silika pada batu candi yang ditumbuhi lumut lebih rendah jika dibandingkan dengan yang tidak ditumbuhi lumut. Hal ini karena proses pelapukan yang terjadi menyebabkan berkurangnya kadar silika pada batu. Selain itu, kandungan kalium pada batu candi yang ditumbuhi lumut lebih tinggi jika dibandingkan dengan yang tidak ditumbuhi lumut, karena kalium merupakan unsur yang sangat diperlukan untuk pertumbuhan lumut.

Batu candi yang mengalami penggaraman memiliki densitas lebih kecil dan porositas lebih besar jika dibandingkan batu candi yang tidak mengalami penggaraman. Kandungan silika pada batu candi yang mengalami penggaraman lebih rendah jika dibandingkan dengan yang tidak mengalami penggaraman. Hal ini disebabkan oleh proses penggaraman yang salah satunya melarutkan silika dan kemudian mengendapkannya di permukaan batu.
\end{abstract}

Kata Kunci : Candi Borobudur, karakteristik, batu, andesit, lumut, penggaraman, silika

Abstrak : Borobudur Temple is one of Indonesia's cultural heritages, which has been enlisted as world cultural heritage. It is composed by andesite that, studied at specifically, has different characteristics causing differences in level of damage and weathering. The determination of Borobudur Temple's stone characteristics is based of parameter of physical nature, chemical composition and stone mineralogy.

Dark-colored stone has bigger density compares to bright-colored one, because it has higher content of ferromagnesium. Moreover, dark-colored stone is able to absorb heat better that the bright-colored one.

Moss-covered stone has smaller density and bigger porosity compares to non moss-covered one. The content of silica on moss-covered stone is lower than the non moss-covered one. It occurs because the present weathering process has caused the decrease of silica content in the stone. Moreover, the content of potassium on moss-covered stone is higher than the non moss-covered one, because potassium is needed especially for moss growth.

Salting stone has lower density and bigger porosity compares to non-salting one. The content of silica on salting stone is lower that the non-salting one. It occurs because the salting would dissolve the silica and precipitate in stone surface.

Keywords : Borobudur Temple, characteristic, stone, andesite, moss, salting, sillica

\section{A. Latar Belakang}

Candi Borobudur merupakan salah satu warisan budaya Indonesia yang telah diakui sebagai salah satu warisan budaya dunia. Candi Borobudur dibangun sekitar tahun 800-an Masehi oleh para penganut agama Buddha Mahayana pada masa pemerintahan Raja Samaratungga yang berasal dari wangsa atau Dinasti Syailendra, dan merupakan tempat pemujaan bagi pemeluk agama Buddha. Candi Borobudur terletak di Desa Borobudur, Kecamatan Borobudur, Kabupaten Magelang. Secara astronomis Candi Borobudur terletak pada 7०36'28” lintang selatan dan 110`12'13" bujur timur.

Candi Borobudur tersusun oleh andesit yang memiliki porositas tinggi. Karena porositas tinggi inilah, andesit penyusun Candi Borobudur memiliki kuat tekan yang tergolong rendah jika dibandingkan 
dengan batuan sejenis (Sampurno, 1969). Andesit dipilih karena ketersediaannya yang banyak, mengingat gunung api di Pulau Jawa kebanyakan mengandung magma intermediet dan membeku ketika mencapai puncak, sehingga menghasilkan batuan beku jenis andesit. Andesit termasuk dalam batuan beku intermediet dengan kandungan silika 52$66 \%$, memiliki tekstur porfiroafanitik yaitu fenokris (butiran kristal) dikelilingi oleh massa dasar yang afanitik (halus), dengan komposisi mineral utama plagioklas, mineral aksesori hornblende, biotit, piroksen dan massa dasar dapat berupa mineral felsic (asam, warna cerah) atau mineral mafic (basa, warna gelap). Sedangkan batu candi dipilih yang memiliki porositas tinggi, karena dengan porositas tinggi maka batuan akan lebih mudah dipahat.

Meskipun secara umum penyusun Candi Borobudur merupakan batu yang sejenis (andesit), namun jika dibedakan secara spesifik batu-batu penyusun tersebut memiliki karakteristik yang berbeda, sehingga memiliki tingkat kerusakan dan pelapukan yang berbeda. Kerusakan dan pelapukan ini banyak sekali macamnya, yang disebabkan oleh faktor penyebab yang berbeda-beda pula. Karena itu, perlu diketahui karakteristik yang spesifik untuk tiap-tiap batu berdasarkan parameter-parameter yang ada. Menurut Siregar (2011), proses kerusakan dan pelapukan yang terjadi pada batu penyusun Candi Borobudur dapat dikelompokkan dalam 4 macam, yaitu :

1. Kerusakan mekanis

Kerusakan material batuan yang disebabkan oleh gaya-gaya mekanis, seperti pembebanan dan getaran

2. Pelapukan fisik

Pelapukan material batuan yang disebabkan oleh adanya faktor fisik seperti suhu, kelembaban, angin, air hujan, penguapan, dan akan menghasilkan gejala-gejala seperti pengelupasan dan aus

3. Pelapukan kimia

Pelapukan yang terjadi pada material batuan sebagai akibat dari proses atau reaksi kimiawi seperti penggaraman dan korosi

4. Pelapukan biologis
Pelapukan pada material yang disebabkan oleh adanya kegiatan mikroorganisme seperti pertumbuhan lumut, alga, dan lichen.

Beberapa penelitian tentang batu penyusun Candi Borobudur pernah dilakukan sebelumnya. Penelitian yang dilakukan Leisen, dkk (2012) menerangkan bahwa pola dan tingkat pelapukan pada setiap individu blok batu sangat tergantung pada varietas batunya. Ada perbedaan tingkat pelapukan yang signifikan untuk varietas batu yang berbeda. Selain itu, penelitian mengenai karakteristik material di situs dan di laboratorium menunjukkan karakteristik fisik seperti penyerapan air sangat berbeda untuk tiap varietas batu yang berbeda. Ariyanto (1993) menerangkan bahwa faktor utama yang menyebabkan terjadinya pengelupasan batu penyusun Candi Borobudur adalah akibat pemuaian dan pengerutan yang berbeda antara mineral-mineral pembentuk batuan dengan endapan garam.

\section{B. Kondisi Batuan di Lapangan}

Candi Borobudur tersusun atas andesit. Namun jika diamati, andesit penyusun Candi Borobudur memiliki beberapa macam karakteristik, misalnya dilihat dari segi warna, pertumbuhan lumut maupun munculnya endapan garam. Dari hasil pengamatan di lapangan, andesit penyusun Candi Borobudur dapat dikelompokkan menjadi 5 macam warna, yaitu: abu-abu, abu-abu kecokelatan, abu-abu kehitaman, kemerahan dan hitam (Gambar 1), meskipun jika diamati lebih jauh perbedaan warna batuan terlihat secara gradasional, sehingga macam warna batu bisa

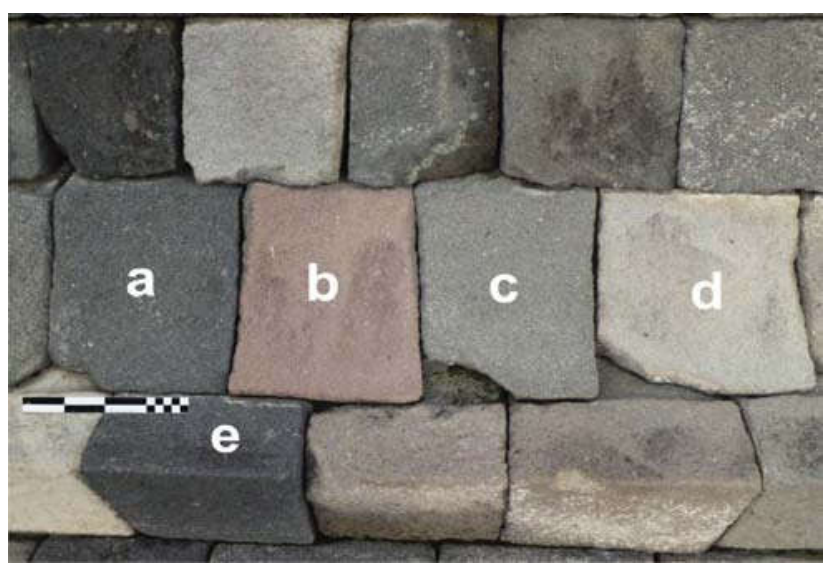

Gambar 1. Variasi warna batu Candi Borobudur (a)abu-abu kehitaman, (b)kemerahan, (c)abu-abu, (d)abu-abu kecokelatan, (e)hitam 


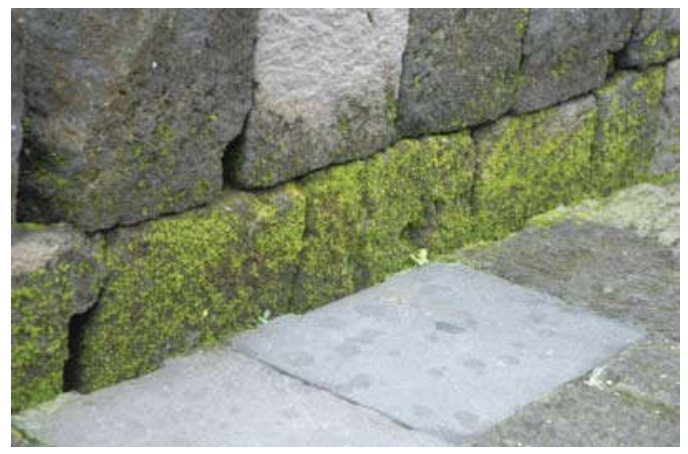

Gambar 2. Blok batu yang ditumbuhi lumut

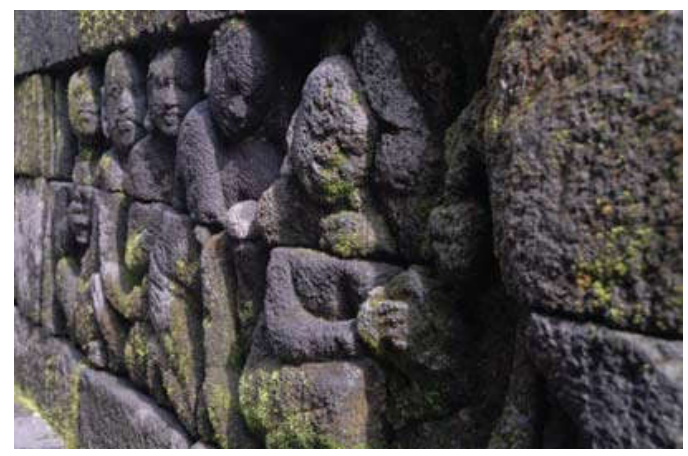

Gambar 3. Relief pada batu yang ditumbuhi lumut

sangat banyak dan relatif (subjektif).

Pelapukan yang terjadi pada batu Candi Borobudur salah satunya disebabkan oleh tumbuhan tingkat rendah seperti lumut yang tumbuh pada permukaan batu (Gambar 2 dan 3). Hasil pengamatan di lapangan menunjukkan, pertumbuhan lumut pada tiap blok batu tidak sama. Ada blok batu yang banyak ditumbuhi oleh lumut, di sisi lain ada juga blok batu yang bersih dari pertumbuhan lumut. Hal ini disebabkan oleh faktor internal maupun eksternal. Faktor eksternal antara lain adalah keberadaan air yang membuat batuan menjadi lembab maupun intensitas sinar matahari. Sedangkan faktor internal sangat erat kaitannya dengan karakteristik batu itu sendiri, antara lain porositas, daya serap air maupun unsur yang terkandung dalam batu tersebut.

Jenis pelapukan lain yang terjadi pada batu Candi Borobudur adalah pelapukan kimia yang berupa penggaraman. Munculnya penggaraman ini disebabkan oleh unsur yang ada pada batu terlarut oleh air dan keluar melalui pori-pori batu akibat penguapan lalu mengendap di permukaan batu. Karena itulah banyak faktor yang menyebabkan penggaraman terjadi baik faktor internal maupun eksternal. Faktor eksternal yang bekerja adalah air,

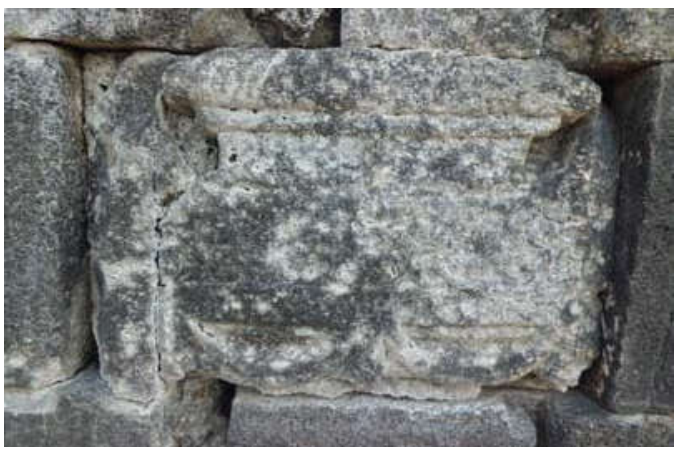

Gambar 4. Penggaraman pada batu Candi Borobudur

karena keberadaan air ini dapat melarutkan unsur yang terkandung pada batu. Selain itu faktor internal juga sangat mempengaruhi terjadinya penggaraman, seperti keberadaan unsur yang dapat terlarut oleh air maupun porositas batuan, karena keberadaan poripori pada batuan ini menjadi celah untuk keluarnya hasil pelarutan yang pada akhirnya akan mengendap di permukaan batuan.

Selanjutnya yang dilakukan adalah analisis sifat fisik, komposisi kimia, maupun mineralogi batuan. Oleh karena analisis yang dilakukan bersifat destruktif, maka sampel andesit diambil dari batu candi yang ada di tempat penyimpanan batu (kondisinya relatif sama dengan di candi/di tempat terbuka) yang terletak di sebelah barat Candi Borobudur, sehingga tidak merusak batu yang ada di candi. Sampel yang diambil adalah andesit yang terdiri dari 5 macam warna dan andesit yang ditumbuhi lumut maupun yang telah mengalami penggaraman. Setelah itu dilakukan pengkodean batu :

$\begin{array}{ll}\text { BDR } 1 & \text { : andesit warna abu-abu } \\ \text { BDR 2 } & \text { : andesit warna abu-abu kecokelatan } \\ \text { BDR } 3 & \text { : andesit warna abu-abu kehitaman } \\ \text { BDR } 4 & \text { : andesit warna kemerahan } \\ \text { BDR 5 } & \text { : andesit warna hitam }\end{array}$

\section{Sifat Fisik Batuan}

Analisis sifat fisik batu yang dilakukan di laboratorium meliputi densitas, berat jenis, porositas, daya serap air, kekerasan dan temperatur. Hasil analisis sifat fisik batu yang dilakukan dapat dilihat pada Tabel 1. Selanjutnya dilakukan interpretasi hasil analisis untuk membandingkan karakteristik sifat fisik untuk tiap-tiap batu. 
Tabel 1. Sifat fisik batu penyusun Candi Borobudur

\begin{tabular}{lccccc}
\multicolumn{1}{c}{ Parameter } & BDR 1 & BDR 2 & BDR 3 & BDR 4 & BDR 5 \\
\hline Densitas $\left(\mathrm{gr} / \mathrm{cm}^{3}\right)$ & 2,14 & 2,12 & 2,21 & 2,18 & 2,23 \\
\hline Berat Jenis & 2,67 & 2,63 & 2,7 & 2,68 & 2,71 \\
Porositas (\%) & 19,45 & 20,35 & 18,78 & 19,24 & 17,96 \\
Daya serap air (\%) & 10,68 & 10,94 & 9,78 & 10,23 & 9,25 \\
Kekerasan (skala mohs) & $4-6$ & $4-6$ & $4-6$ & $4-6$ & $4-6$ \\
Temperatur batu $\left({ }^{\circ} \mathrm{C}\right)$ & 45,2 & 44,7 & 47,1 & 45,9 & 48,6
\end{tabular}

Keterangan :

Sampel yang dianalisis dipilih andesit yang paling segar (tidak ditumbuhi lumut/menggalami penggaraman)

Nilai tiap-tiap parameter sifat fisik didapatkan dari rata-rata beberapa sampel batu yang warnanya sama

Temperatur batu diukur diukur pada bulan Agustus $2013 \mathrm{jam} \pm 11.00$

Dari tabel sifat fisik batu penyusun Candi Borobudur (Tabel 1), densitas sampel BDR 5 (hitam) memiliki nilai yang paling tinggi. Berturut-turut yang memiliki nilai densitas dari besar ke kecil yaitu BDR 3 (abu-abu kehitaman), BDR 4 (kemerahan), BDR 1 (abu-abu) dan BDR 2 (abu-abu kecokelatan). Nilai densitas yang lebih tinggi untuk batu berwarna gelap, sesuai dengan teorinya memiliki kandungan ferro magnesium yang lebih tinggi, sehingga menyebabkan densitasnya juga lebih tinggi. Nilai berat jenis batu candi mengikuti pola yang sama dengan densitasnya, dimana batu yang memiliki berat jenis yang lebih tinggi, densitasnya juga lebih tinggi. Nilai berat jenis dan densitas ini berbanding terbalik dengan nilai porositas maupun daya serap airnya. Hal ini karena batuan dengan rapat massa yang lebih besar akan memiliki volume pori yang lebih kecil.

Untuk kekerasan batu, nilai yang didapatkan relatif sama yaitu 4 - 6 skala mohs. Nilai kekerasan 6 skala mohs didapat pada batuan yang tekstur permukannya halus (pori-pori batu kecil), sedangkan nilai kekerasan 4 skala mohs didapat dari andesit yang tekstur permukaannya kasar.

Untuk pengukuran temperatur, andesit dengan warna gelap mampu menyerap panas yang lebih besar dibandingkan dengan andesit berwarna cerah. Hal ini disebabkan andesit berwarna gelap memiliki kandungan ferro magnesium yang lebih tinggi, sehingga kemampuan menyerap dan menyimpan panas juga lebih tinggi.

\section{Komposisi Kimia Batuan}

Batu penyusun Candi Borobudur yang berjenis andesit tersusun atas komposisi kimia yang terdiri dari unsur-unsur utama yaitu silikat, aluminium, besi, kalsium, magnesium, natrium, dan kalium. Dari hasil analisis kimia batu penyusun Candi Borobudur didapatkan komposisi kimia yang tertera pada Tabel 2.

Hasil analisis komposisi kimia andesit Candi Borobudur menunjukkan bahwa andesit berwarna cerah relatif memiliki kandungan silika lebih tinggi daripada andesit berwarna gelap. Selanjutnya untuk kandungan besi $(\mathrm{Fe})$, andesit berwarna gelap memiliki nilai yang lebih tinggi dari andesit berwarna terang. Hal ini karena kandungan mineral mafik (ferro magnesium silikat) lebih tinggi, sehingga menyebabkan warna yang lebih gelap.

Tabel 2. Komposisi kimia batu penyusun Candi Borobudur

\begin{tabular}{cccccc} 
Parameter & BDR 1 (\%) & BDR 2 (\%) & BDR 3 (\%) & BDR 4 (\%) & BDR 5 (\%) \\
\hline $\mathrm{Al}_{2} \mathrm{O}_{3}$ & 16,93 & 17,19 & 14,35 & 15,47 & 13,00 \\
\hline $\mathrm{CaO}$ & 2,68 & 2,60 & 3,89 & 3,50 & 1,96 \\
$\mathrm{FeO}$ & 4,78 & 4,62 & 6,03 & 5,37 & 6,78 \\
\hline $\mathrm{Fe}_{2} \mathrm{O}_{3}$ & 5,31 & 5,14 & 6,71 & 5,97 & 7,53 \\
\hline $\mathrm{MgO}$ & 1,57 & 0,62 & 1,55 & 0,62 & 1,29 \\
$\mathrm{Na}_{2} \mathrm{O}$ & 3,81 & 3,50 & 4,13 & 4,02 & 3,29 \\
$\mathrm{~K}_{2} \mathrm{O}$ & 2,83 & 2,35 & 2,65 & 2,88 & 2,73 \\
$\mathrm{SiO}_{2}$ & 59,69 & 59,97 & 58,15 & 58,20 & 56,12 \\
\hline
\end{tabular}

Keterangan :

Sampel yang dianalisis dipilih andesit yang paling segar (tidak ditumbuhi lumut/menggalami penggaraman) 


\section{E. Mineralogi Batuan}

Identifikasi karakteristik batuan dari aspek tekstur dan komposisi mineralogi dilakukan dengan analisis petrografi menggunakan mikroskop polarisasi. Dari analisis petrografi yang dilakukan pada sayatan tipis andesit penyusun Candi Borobudur, terlihat kenampakan yang sama dari segi tekstur dan komposisi mineral. Datanya adalah sebagai berikut :

- BDR 1

Warna abu-abu kecokelatan, tekstur porfiritik, bentuk subhedral-anhedral, komposisi mineral terdiri dari fenokris berupa plagioklas (25\%), piroksen (15\%), mineral opak (5\%) dan massa dasar berupa plagioklas (35\%) dan gelas vulkanik (20\%).

\section{- BDR 2}

Warna abu-abu kecokelatan, tekstur porfiritik, bentuk subhedral-anhedral, komposisi mineral terdiri dari fenokris berupa plagioklas (30\%), piroksen (15\%), mineral opak (5\%) dan massa dasar berupa plagioklas (30\%) dan gelas vulkanik (20\%).

\section{- BDR 3}

Warna abu-abu kecokelatan, tekstur porfiritik, bentuk subhedral-anhedral, komposisi mineral terdiri dari fenokris berupa plagioklas (20\%), piroksen (20\%), mineral opak (5\%) dan massa dasar berupa plagioklas (35\%) dan gelas vulkanik (20\%).

\section{- BDR 4}

Warna abu-abu kecokelatan, tekstur porfiritik, bentuk subhedral-anhedral, komposisi mineral terdiri dari fenokris berupa plagioklas (25\%), piroksen (20\%), mineral opak (5\%) dan massa dasar berupa plagioklas (30\%) dan gelas vulkanik (20\%).

\section{- BDR 5}

Warna abu-abu kecokelatan, tekstur porfiritik, bentuk subhedral-anhedral, komposisi mineral terdiri dari fenokris berupa plagioklas (20\%), piroksen (20\%), mineral opak (5\%) dan massa dasar berupa plagioklas (30\%) dan gelas vulkanik $(25 \%)$.

Dari analisis petrografi tersebut menunjukkan bahwa andesit penyusun Candi Borobudur tersusun atas mineral yang sama yaitu plagioklas, piroksen, mineral opak dan gelas vulkanik, yang membedakan hanyalah pada persentase komposisinya saja. Plagioklas yang ada berjenis andesin. Andesit yang berwarna lebih cerah relatif memiliki kandungan plagioklas lebih tinggi dibandingkan yang berwarna lebih gelap. Sedangkan untuk kandungan piroksen, andesit yang berwarna lebih gelap memiliki komposisi lebih tinggi dibandingkan andesit yang berwarna lebih cerah.

\section{F. Karakteristik Batu Candi Borobudur dan Hubungannya dengan Pertumbuhan Lumut}

Batu penyusun Candi Borobudur yang tersusun atas andesit sebagian telah mengalami pelapukan. Faktor yang berpengaruh terhadap pelapukan batu Candi Borobudur terdiri dari dua macam, yaitu faktor eksternal dan internal. Faktor eksternal yang berpengaruh antara lain keberadaan air, fluktuasi suhu, dan aktifitas organisme, sedangkan faktor internal yang berpengaruh adalah dari karakteristik batu itu sendiri.

Lumut yang merupakan tumbuhan tingkat rendah menjadi salah satu faktor penyebab pelapukan batu Candi Borobudur. Tumbuhnya lumut pada batu candi, selain disebabkan karena faktor air (kelembaban) juga dipengaruhi oleh karakteristik batu itu sendiri. Alasan mengapa karakteristik batu menjadi salah satu faktor pertumbuhan lumut ini, disimpulkan dari fakta bahwa tidak semua batu Candi Borobudur ditumbuhi oleh lumut, bahkan ada blok batu yang bersinggungan langsung, sebagian ditumbuhi lumut dan sebagian bersih dari pertumbuhan lumut (Gambar 5 dan 6).

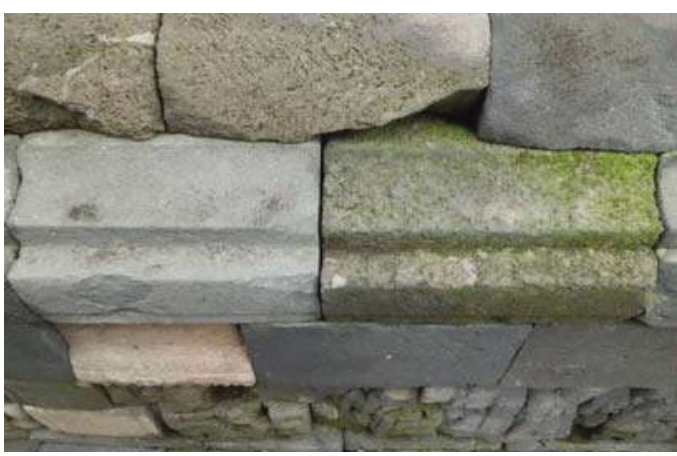

Gambar 5. Blok batu yang ditumbuhi lumut dan yang tidak 


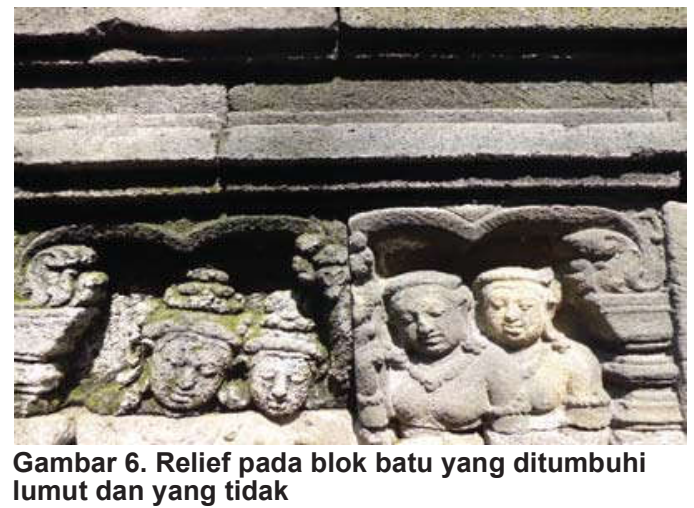

Dari Gambar 5 dan 6 secara sepintas terlihat bahwa permukaan batu yang ditumbuhi lumut memiliki tekstur yang lebih kasar jika dibandingkan dengan batu yang bersih dari pertumbuhan lumut. Karena itulah diperlukan analisis sifat fisik dan kimia batuan untuk menjelaskan penyebabnya. Dari analisis sifat fisik yang dilakukan di laboratorium terhadap 3 sampel batu penyusun Candi Borobudur yang ditumbuhi lumut didapatkan hasil seperti pada Tabel 3.

Dari analisis fisik pada Tabel 3 terlihat bahwa batu candi yang ditumbuhi lumut memiliki nilai densitas antara 2,02-2,07 gr/ $\mathrm{cm}^{3}$. Nilai ini lebih kecil dari nilai densitas batu penyusun Candi Borobudur yang tidak ditumbuhi lumut (Tabel 1). Pada Tabel 1 mengenai sifat fisik batu penyusun Candi Borobudur (Tabel 1), nilai densitas batu berkisar antara 2,12 $2,23 \mathrm{gr} / \mathrm{cm}^{3}$. Hal ini menunjukkan bahwa lumut tumbuh pada batu dengan rapat massa yang relatif lebih kecil. Hal ini disebabkan batu yang memiliki rapat massa lebih kecil memiliki pori-pori yang lebih besar, sehingga akan dapat menyerap dan menyimpan air lebih besar pula yang mengakibatkan kelembaban batu akan lebih tinggi (menunjang pertumbuhan lumut). Hal ini juga sesuai dengan nilai porositas batu candi yang ditumbuhi lumut (Tabel 3) yaitu berkisar antara 22,85 - 23,81\%, yang lebih tinggi dari porositas batu penyusun Candi Borobudur yang tidak ditumbuhi lumut (Tabel 1) yang berkisan antara $17,96-20,85 \%$.

Dari segi kekerasan, batu yang ditumbuhi lumut memiliki kekerasan \pm 4 skala mohs (Tabel 3 ), yang merupakan nilai kekerasan paling rendah dari batu penyusun Candi Borobudur yang tidak ditumbuhi lumut (kekerasan 4 - 6 skala mohs, tertera pada Tabel 1). Hal ini dipengaruhi oleh densitas dan porositas batu yang memungkinkan terjadinya pelapukan lebih cepat, sehingga menyebabkan kekerasan batu menjadi rendah. Pelapukan menjadi semakin intensif karena adanya pertumbuhan lumut. Hal ini karena rhizoid lumut menembus ke dalam batuan mengikuti sistem pori-pori yang dapat menyebabkan dinding-dinding di antara pori-pori menjadi pecah (Samidi, 1975).

Selain analisis fisik juga dilakukan analisis kimia untuk mengetahui komposisi kimia batu penyusun Candi Borobudur yang ditumbuhi lumut. Dari analisis kimia yang dilakukan di laboratorium terhadap 2 sampel batu penyusun Candi Borobudur yang ditumbuhi lumut didapatkan hasil yang tertera pada Tabel 4.

Dari Tabel 4 terlihat bahwa komposisi kimia batu candi yang ditumbuhi lumut memiliki kandungan $\mathrm{SiO}_{2}$ yang lebih kecil dari batu penyusun Candi Borobudur yang tidak ditumbuhi lumut (Tabel 2). Dari analisis kimia yang dilakukan pada dua sampel batu candi yang ditumbuhi lumut didapatkan

Tabel 3. Sifat fisik batu penyusun Candi Borobudur yang ditumbuhi lumut

\begin{tabular}{lccc}
\multicolumn{1}{c}{ Parameter } & BDR 6 & BDR 7 & BDR 8 \\
Densitas ( $\mathrm{gr} / \mathrm{cm}^{3}$ ) & 2,02 & 2,07 & 2,05 \\
Porositas (\%) & 23,81 & 22,85 & 23,31 \\
\hline Kekerasan (skala mohs) & \pm 4 & \pm 4 & \pm 4
\end{tabular}

Tabel 4. Komposisi kimia batu penyusun Candi Borobudur yang ditumbuhi lumut

\begin{tabular}{|ccc|}
\hline Parameter & BDR 6 & BDR 7 \\
\hline $\mathrm{Al}_{2} \mathrm{O}_{3}$ & $17,82 \%$ & $15,41 \%$ \\
\hline $\mathrm{CaO}$ & $4,56 \%$ & $4,04 \%$ \\
\hline $\mathrm{FeO}$ & $8,19 \%$ & $7,21 \%$ \\
\hline $\mathrm{Fe}_{2} \mathrm{O}_{3}$ & $9,11 \%$ & $8,02 \%$ \\
\hline $\mathrm{MgO}$ & $1,71 \%$ & $1,76 \%$ \\
\hline $\mathrm{Na}_{2} \mathrm{O}$ & $4,20 \%$ & $3,80 \%$ \\
\hline $\mathrm{K}_{2} \mathrm{O}$ & $3,63 \%$ & $3,51 \%$ \\
\hline $\mathrm{SiO}_{2}$ & $47,36 \%$ & $52,47 \%$ \\
\hline
\end{tabular}


nilai $\mathrm{SiO}_{2} 47,36 \%$ dan 52,47\%. Nilai tersebut lebih kecil dari nilai $\mathrm{SiO}_{2}$ pada batu candi yang tidak ditumbuhi lumut (Tabel 2) yang berkisar antara $56,12 \%-59,97 \%$. Rendahnya kandungan $\mathrm{SiO}_{2}$ pada batu yang ditumbuhi lumut karena proses pelapukan menyebabkan berkurangnya kadar silika pada batu.

Hal ini sesuai dengan yang dikemukakan oleh Lounghnan (1969) bahwa pelapukan memiliki 3 tahapan penting yaitu :

a. Hancurnya struktur mineral asal dengan disertai oleh pembebasan silika,

b. Terpindahnya beberapa komponen batuan yang lapuk,

c. Terbentuknya mineral baru yang stabil pada kondisi lingkungan.

Selain itu dari komposisi kimia batuan terlihat bahwa batu yang ditumbuhi lumut memiliki kandungan kalium lebih tinggi dari batu yang tidak ditumbuhi lumut. Kalium merupakan unsur yang sangat diperlukan untuk pertumbuhan lumut. Fungsi kalium bagi pertumbuhan lumut antara lain :

a. Membentuk dan mengangkut karbohidrat,

b. Sebagai katalisator dalam pembentukan protein,

c. Menetralkan reaksi dalam sel terutama dari asam organik.

Kalium diserap dalam bentuk ion $\mathrm{K}^{+}$. Dari analisis 2 batu yang ditumbuhi lumut, didapat nilai $\mathrm{K}_{2} \mathrm{O} \quad 3,51 \%$ dan 3,63 \%. Nilai ini lebih tinggi dari kandungan $\mathrm{K}_{2} \mathrm{O}$ batu yang tidak ditumbuhi lumut yang berkisar antara 2,35\%-2,88\%. Hal ini menandakan bahwa batu yang memiliki kandungan kalium lebih tinggi relatif lebih mudah ditumbuhi lumut, meskipun masih banyak faktor lain yang berpengaruh dalam pertumbuhan lumut seperti telah diuraikan sebelumnya.

\section{G. Karakteristik Batu Candi Borobudur dan Hubungannya dengan Endapan Garam pada Permukaan Batu}

Selain pertumbuhan lumut, penyebab pelapukan pada batu penyusun Candi Borobudur yang lain adalah munculnya endapan garam pada permukaan batu. Akibat pengaruh suhu lingkungan dan penyinaran matahari serta faktor-faktor lain, air yang terakumulasi pada batu akan menguap. Pada proses penguapan air melalui pori-pori batu, air membawa bahan-bahan mineral terlarut ke permukaan batu. Ketika air menguap, bahan-bahan mineral terlarut akan tertinggal di permukaan batu sehingga dalam jangka waktu tertentu terakumulasi menjadi endapan garam yang tebal (Sudibyo, 2002).

Karakteristik batu yang meliputi sifat fisik dan komposisi kimia batu menjadi faktor penting dalam proses penggaraman, ditunjukkan bahwa tidak semua batu Candi Borobudur menggalami penggaraman. Bahkan ada blok batu yang bersebelahan, sebagian mengalami penggaraman dan sebagian tidak mengalami penggaraman (Gambar 8). Oleh karena itulah sangat penting untuk mengidentifikasi karakteristik batu seperti tingkat porositas maupun unsur yang terkandung dalam batu dan endapan garam.

Dari analisis sifat fisik yang dilakukan terhadap 2 sampel batu candi yang mengalami penggaraman, didapatkan hasil yang tertera pada Tabel 5. Dari Tabel 5 terlihat bahwa nilai densitas adalah 2,03 dan 2,05 $\mathrm{gr} / \mathrm{cm}^{3}$. Nilai ini lebih kecil dari nilai densitas batu penyusun Candi Borobudur yang tidak mengalami
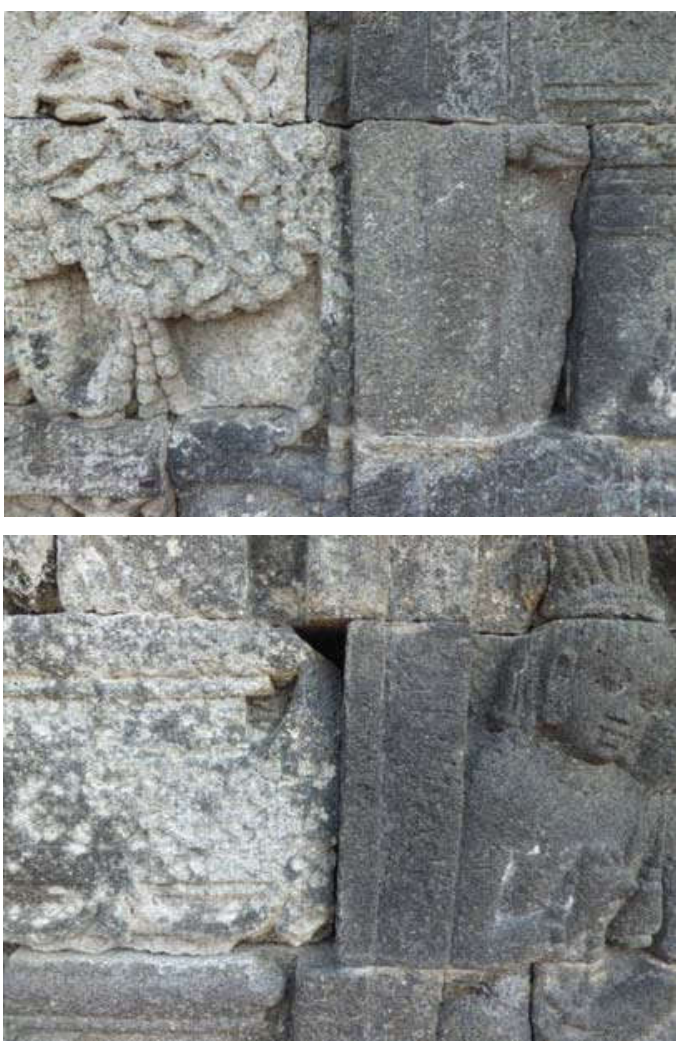

Gambar 8. Relief pada batu yang mengalami penggaraman dan yang tidak 
penggaraman (Tabel 1). Pada Tabel 1 mengenai sifat fisik batu penyusun Candi Borobudur, diketahui nilai densitas batu berkisar antara 2,12-2,23 gr/ $\mathrm{cm}^{3}$. Hal ini menunjukkan bahwa endapan garam muncul pada batu yang memiliki rapat massa relatif lebih kecil. Hal ini karena batuan yang memiliki rapat massa lebih kecil memiliki pori-pori lebih besar, sehingga dapat menyerap dan menyimpan air lebih banyak, kemudian menyebabkan pelarutan unsur-unsur yang terkandung di dalamnya akan lebih intensif. Hal ini juga sesuai dengan nilai porositas yang dimiliki yaitu 23,15\% dan 23,36\% (Tabel 5), yang lebih tinggi dari nilai porositas batu penyusun Candi Borobudur tidak mengalami pengaraman (Tabel 1) yang berkisar antara 17,96 - 20,85 \%. Dari segi kekerasan batu yang mengalami penggaraman memiliki kekerasan \pm 4 skala mohs. Hal ini dipengaruhi oleh densitas dan porositas batu yang memungkinkan terjadinya pelapukan lebih cepat, sehingga menyebabkan kekerasan batu menjadi rendah. Nilai kekerasan ini lebih rendah dari kekerasan endapan garam yang ada di permukaannya yang mencapai 5 - 6 skala mohs. Tingkat kekerasan endapan garam yang tinggi menjadi salah satu sebab mengapa pada permukaan batu yang mengalami penggaraman tidak ditumbuhi lumut. Lumut hanya tumbuh pada bagian tertentu saja, pada umumnya mengumpul di lubang-lubang alveol dan pori-pori yang tidak tertutup endapan garam. Pertumbuhan lumut pada blok batu yang mengalami penggaraman dapat dilihat pada Gambar 9.

Selain analisis fisik, juga dilakukan analisis kimia
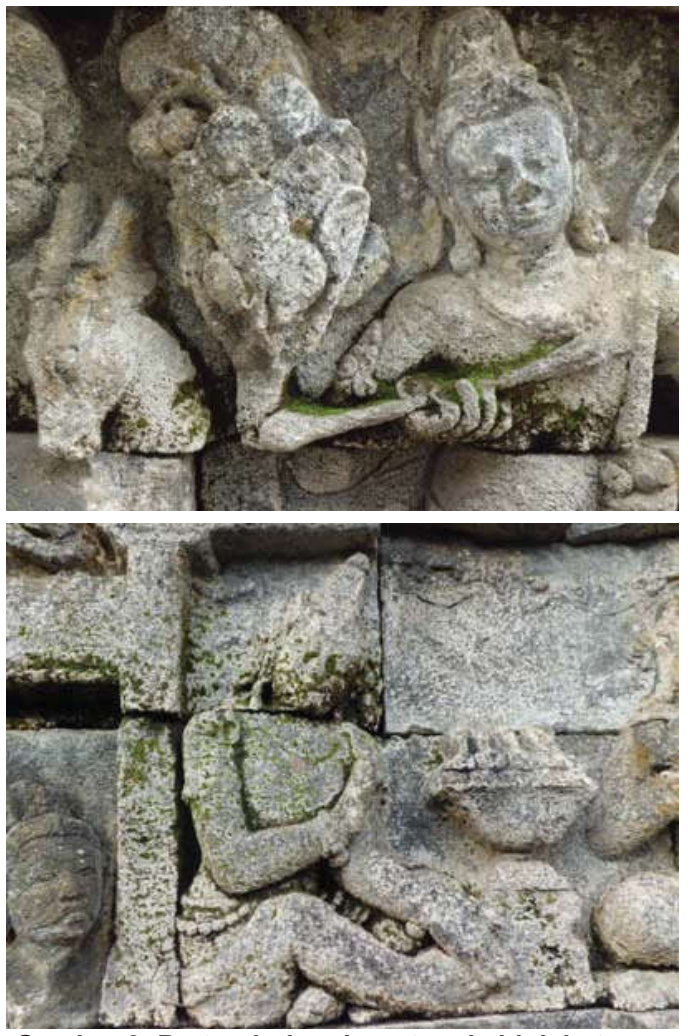

Gambar 9. Pertumbuhan lumut pada blok batu yang mengalami penggaraman

untuk mengetahui komposisi kimia batu penyusun Candi Borobudur yang mengalami penggaraman. Dari analisis kimia di laboratorium terhadap sampel batu penyusun Candi Borobudur yang mengalami penggaraman didapatkan hasil yang tertera pada Tabel 6.

Dari Tabel 6 terlihat bahwa komposisi kimia batu candi yang mengalami penggaraman memiliki kandungan $\mathrm{SiO}_{2}$ lebih kecil dari batu penyusun Candi Borobudur yang tidak mengalami penggaraman (Tabel 2). Dari analisis kimia pada sampel batu candi

Tabel 5. Sifat fisik batu penyusun Candi Borobudur

\begin{tabular}{|lcc|}
\multicolumn{1}{|c|}{ yang mengalami penggaraman } \\
\hline \multicolumn{1}{|c|}{ Parameter } & BDR 9 & BDR 10 \\
\hline Densitas $\left(\mathrm{gr} / \mathrm{cm}^{3}\right)$ & 2,03 & 2,05 \\
\hline Porositas (\%) & 23,15 & 23,36 \\
\hline Kekerasan (skala mohs) & \pm 4 & \pm 4 \\
\hline
\end{tabular}

Tabel 6. Komposisi kimia batu penyusun Candi Borobudur yang mengalami penggaraman

\begin{tabular}{cc|}
\hline Parameter & BDR 9 \\
\hline $\mathrm{Al}_{2} \mathrm{O}_{3}$ & 20,55 \\
\hline $\mathrm{CaO}$ & 4,15 \\
\hline $\mathrm{FeO}$ & 7,73 \\
\hline $\mathrm{Fe}_{2} \mathrm{O}_{3}$ & 8,60 \\
\hline $\mathrm{MgO}$ & 1,55 \\
\hline $\mathrm{Na}_{2} \mathrm{O}$ & 4,16 \\
\hline $\mathrm{K}_{2} \mathrm{O}$ & 3,03 \\
\hline $\mathrm{SiO}_{2}$ & 47,34 \\
\hline
\end{tabular}


yang mengalami penggaraman didapatkan nilai $\mathrm{SiO}_{2}$ $47,34 \%$. Nilai ini lebih kecil dari nilai $\mathrm{SiO}_{2}$ pada batu candi yang tidak mengalami penggaraman (Tabel 2) yang berkisar antara 56,12 - 59,97\%. Rendahnya kandungan $\mathrm{SiO}_{2}$ pada batu yang mengalami penggaraman disebabkan oleh proses penggaraman yang salah satunya melarutkan $\mathrm{SiO}_{2}$ dan kemudian mengendap di permukaan batu.

Ini terlihat hasil analisis endapan garam pada permukaan batu Candi Borobudur yang dilakukan oleh peneliti sebelumnya. Septiningrum (2007) menganalisis 4 sampel endapan garam yang diambil pada permukaan batu di ke-4 sisi Candi Borobudur. Hasilnya tertera pada Tabel 7.

Dari Tabel 7 terlihat bahwa komposisi kimia endapan garam pada permukaan batu Candi Borobudur mayoritas tersusun atas silika, karbonat, kalsium dan magnesium. Silika $\left(\mathrm{SiO}_{2}\right)$ larut dalam air yang terakumulasi pada pori-pori batu membentuk asam silikat $\left(\mathrm{H}_{4} \mathrm{SiO}_{4}\right)$. Karena proses penguapan air melalui pori-pori batu, silika akan mengendap di permukaan batu. Reaksinya adalah sebagai berikut :

$$
\mathrm{H}_{4} \mathrm{SiO}_{4(\mathrm{aq})} \longrightarrow \mathrm{SiO}_{2(\mathrm{~s})}+2 \mathrm{H}_{2} \mathrm{O}
$$

Adapun senyawa karbonat muncul karena unsur yang ada dalam batu mengalami kontak dengan air hujan. Reaksinya adalah sebagai berikut :

$$
\begin{aligned}
& \mathrm{CO}_{2}+\mathrm{H}_{2} \mathrm{O} \longrightarrow \mathrm{H}_{2} \mathrm{CO}_{3(\mathrm{aq})} \\
& \mathrm{CaO}_{(\mathrm{s})}+\mathrm{H}_{2} \mathrm{CO}_{3(\mathrm{aq})} \longrightarrow \mathrm{CaCO}_{3(\mathrm{~s})}+\mathrm{H}_{2} \mathrm{O} \\
& \mathrm{MgO}_{(\mathrm{s})}+\mathrm{H}_{2} \mathrm{CO}_{3(\mathrm{aq})} \longrightarrow \mathrm{MgCO}_{3(\mathrm{~s})}+\mathrm{H}_{2} \mathrm{O}
\end{aligned}
$$

Dari reaksi di atas terlihat bahwa kalsium dan magnesium bereaksi dengan $\mathrm{H}_{2} \mathrm{CO}_{3}$ dan mengalami pelarutan. Selanjutnya, karena proses penguapan air melalui pori-pori batu, garam karbonat akan mengendap di permukaan batu dalam bentuk $\mathrm{CaCO}_{3}$ dan $\mathrm{MgCO}_{3}$. Hal ini yang membuat endapan garam pada permukaan batu banyak mengandung karbonat, kalsium, dan magnesium.

\section{H. Penutup}

Candi Borobudur tersusun oleh batu yang sejenis yaitu andesit. Meskipun demikian, andesit penyusun Candi Borobudur memiliki karakteristik yang berbeda-beda sehingga memiliki tingkat kerusakan dan pelapukannya yang berbeda. Karakteristik batu penyusun Candi Borobudur antara lain :

1. Batu candi yang berwarna gelap memiliki densitas lebih besar dibandingkan batu candi yang berwarna cerah, karena kandungan ferro magnesium-nya lebih tinggi. Selain itu batu candi yang berwarna gelap mampu menyerap panas lebih besar dibandingkan dengan batu candi yang berwarna cerah.

2. Batu candi yang berwarna cerah memiliki kandungan silika lebih tinggi dan kandungan besi $(\mathrm{Fe})$ lebih rendah daripada batu candi yang berwarna gelap.

3. Batu candi yang ditumbuhi lumut memiliki

\begin{tabular}{|c|c|c|c|c|c|c|}
\hline \multirow[t]{2}{*}{ No. } & \multirow[t]{2}{*}{ Parameter } & \multicolumn{4}{|c|}{ Endapan Garam (\%) } & \multirow{2}{*}{$\begin{array}{c}\text { Rata-rata } \\
(\%)\end{array}$} \\
\hline & & Sampel A & Sampel B & Sampel C & Sampel D & \\
\hline 1 & Kalsium $\left(\mathrm{Ca}^{+}\right)$ & 15,83 & 13,57 & 14,47 & 12,72 & 14,15 \\
\hline 2 & Magnesium $\left(\mathrm{Mg}^{2+}\right)$ & 10,57 & 8,47 & 9,60 & 9,65 & 9,57 \\
\hline 3 & Aluminium $\left(\mathrm{Al}^{3+}\right)$ & 1,42 & 1,66 & 1,83 & 4,27 & 2,30 \\
\hline 4 & Besi $\left(\mathrm{Fe}^{3+}\right)$ & 3,68 & 2,29 & 3,78 & 4,43 & 3,54 \\
\hline 5 & Sulfat $\left(\mathrm{SO}_{4}{ }^{2-}\right)$ & 2,53 & 2,95 & 1,08 & 2,18 & 2,19 \\
\hline 6 & Klorida $\left(\mathrm{Cl}^{-}\right)$ & 0,41 & 0,43 & 0,27 & 0,40 & 0,38 \\
\hline 7 & Silika $\left(\mathrm{SiO}_{2}\right)$ & 38,62 & 37,05 & 38,50 & 36,07 & 37,56 \\
\hline 8 & Karbonat $\left(\mathrm{CO}_{3}{ }^{2-}\right)$ & 26,94 & 33,57 & 30,47 & 30,29 & 30,32 \\
\hline
\end{tabular}
densitas lebih kecil dan porositas lebih besar jika dibandingkan batu candi yang tidak ditumbuhi

Tabel 7. Hasil analisis endapan garam pada permukaan batu Candi Borobudur (Septiningrum, 2007)

Keterangan :

Sampel A : Endapan garam pada dinding sisi timur lantai 1

Sampel B : Endapan garam pada dinding sisi barat lantai 1

Sampel C : Endapan garam pada dinding sisi utara lantai 1

Sampel D : Endapan garam pada dinding sisi selatan lantai 1 
lumut.

4. Kandungan silika pada batu candi yang ditumbuhi lumut lebih rendah jika dibandingkan dengan yang tidak ditumbuhi lumut. Hal ini karena proses pelapukan yang terjadi menyebabkan berkurangnya kadar silika pada batu.

5. Kandungan kalium pada batu candi yang ditumbuhi lumut lebih tinggi jika dibandingkan dengan yang tidak ditumbuhi lumut. Hal ini karena kalium merupakan unsur yang sangat diperlukan untuk pertumbuhan lumut.

6. Batu candi yang mengalami penggaraman memiliki densitas lebih kecil dan porositas lebih

\section{DAFTAR PUSTAKA}

Ariyanto, Y.B.. 1993. Laporan Studi Konservasi Tentang Penanganan Pengelupasan Batuan Candi Borobudur. Balai Studi dan Konservasi Borobudur. Magelang.

Leisen, H., \& Leisen E.v.P. 2012. Technical Mission to Borobudur World Heritage Site in Indonesia. Cologne University. Germany.

Loughnan, F.C. 1969. Chemical Weathering of Silicate Minerals. Elsevier. New York.

Martini, I.P., Chesworth, W. 1992. Weathering Siol dan Paleosoil. Elsevier. Amsterdam.

Samidi. 1975. Penelitian Pendahuluan Pemberantasan Lumut pada Batuan Candi Borobudur. Pelita Borobudur Seri B No. 7. Departemen Pendidikan dan Kebudayaan. Jakarta

Sampurno. 1969. Penelitian Tanah Dasar Candi Borobudur. Pelita Borobudur Seri B No. 1. Departemen Pendidikan dan Kebudayaan Republik Indonesia. besar jika dibandingkan batu candi yang tidak mengalami penggaraman.

7. Kandungan silika pada batu candi yang mengalami penggaraman lebih rendah jika dibandingkan dengan yang tidak mengalami penggaraman. Hal ini disebabkan oleh proses penggaraman yang salah satunya melarutkan silika dan kemudian mengendapkannya di permukaan batu.
Septiningrum, D.P. 2007. Analisis Endapan Garam pada Permukaan Batu Candi Borobudur. Universitas Islam Indonesia. Yogyakarta.

Siregar, I.M. 2011. Identifikasi Kerusakan dan Pelapukan Batuan. Makalah; disajikan dalam Pelatihan Tenaga Teknis Konservasi Tingkat Menengah. Balai Konservasi Borobudur. Magelang, 25 Juli - 13 Agustus 2011.

Soekmono, R. 1972. Riwayat Usaha Penyelamatan Candi Borobudur. Pelita Borobudur Seri A No. 1. Departemen Pendidikan dan Kebudayaan. Jakarta.

Sudibyo, Suhardi \& Hersaktiningrum. 2002. Studi Proses Penggaraman pada Batu Candi dan Metode Penanganannya. Balai Studi dan Konservasi Borobudur. Magelang. 